\title{
РЕЗИСТЕНТНОСТЬ МОРЕХОЗЯЙСТВЕННОГО КОМПЛЕКСА ЗАПАДНЫХ РЕГИОНОВ РОССИИ В УСЛОВИЯХ ГЕОЭКОНОМИЧЕСКОЙ ТУРБУЛЕНТНОСТИ: ФАКТОРЫ, МЕХАНИЗМЫ, РЕГИОНАЛЬНЫЙ ОПЫТ
}

\author{
(c) 2019 Горочная Василиса Валерьевна \\ кандидат экономических наук, специалист по учебно-методической работе \\ Южный федеральный университет, Россия, Ростов-на-Дону \\ научный сотрудник \\ Балтийский федеральный университет им. И. Канта, Россия, Калининград \\ E-mail: tunduk@hotmail.com
}

Объектом исследования выступает приморская экономика и формы её интеграции (кластеры, ТПК) как ресурс прочности по отношению к внешним колебаниям, предметом - механизмы формирования соответствующих резистентных свойств региона. Проведены теоретико-концептуальное моделирование и эмпирическая диагностика на примере западных регионов России, испытывающих последствия геоэкономической турбулентности.

Ключевые слова: морехозяйственный комплекс, экономические кластеры, резистентность, геоэкономическая турбулентность, западные регионы России.

На сегодняшний день в свете проблем дестабилизации геоэкономических процессов, в особенности проявляющихся в системе «Россия Запад» особую актуальность приобретает поиск путей преодоления турбулентных тенденций и обеспечения поступательного развития современной экономики российских регионов (в первую очередь - приграничных и приморских ареалов, составляющих западную контактнобарьерную зону, зависимую от трансграничного взаимодействия и глубоко интегрированную в систему международного территориального распределения труда) [25], [27]. В связи с этим одним из центральных является вопрос о механизмах возникновения и проявления резистентных свойств региональной экономики, необходимых условиях запуска соответствующих самоорганизующихся процессов [6], [7], [8], в том числе наличии их территориальной и отраслевой специфики.

В некотором смысле «на пересечении» пространственных особенностей регионального хозяйства и отраслевых приоритетов их развития неоднократно рассматривалось развитие морехозяйства как ресурс для повышения прочности экономического развития приморских регионов. Ещё до обострения геоэкономического противостояния, в периоды возникавших в европейском экономическом пространстве кризисов, затрагивающих регионы России, сформировалось мнение о необходимости развития морехозяй- ственного комплекса как «старого и проверенного средства» для стабилизации региональной экономики, что особенно стало очевидным на примере российского региона-эксклава, глубоко интегрированного в европейскую экономику [14]. За последние два десятилетия в исследовательской практике активно освещаются вопросы развития морской и приморской экономики как с точки зрения влияния морского фактора на региональную социально-экономическую систему [25], [26], так и с точки зрения пространственного планирования в русле достижения региональной устойчивости [13].

Обострение глобальной конкуренции, ставящее задачи опережающего развития перед российским морехозяйством для достижения его жизнеспособности в современных условиях, сформировало понимание экономической системы приморского региона как «пространственно-организованной (в пределах территории и акватории) совокупности субъектов экономики и связанных с ними коммерческих и некоммерческих организаций, целевая функция которой направлена на достижение и поддержание конкурентоспособности региона в условиях интеграции и глобализации мирового хозяйства» [20]. В свою очередь, ему соответствует понимание морехозяйственного комплекса как «целостной совокупности взаимодействующих в пределах определенной акватории предприятий и организаций, представляющей собой 
социально-экономическую систему, функциональная доминанта которой заключается в обеспечении конкурентного преимущества регионального хозяйства за счет рационального использования морских ресурсов» [20]. В русле проблем поиска возможностей обеспечения конкурентоспособности отрасли в стратегической перспективе наряду с традиционным для постсоветского пространства концептом комплексообразования [1], [15], [21] широкий дискурс обрели новые формы самоорганизации экономических структур, в особенности - заявленные в рамках кластерного подхода [16], [17], [29]. Наряду с исследованием специфики формирования морехозяйственных кластеров и их особой роли в экономике приморских зон [3], [12], [22], [23] активно исследуются возможности кластерообразования во всех основных географических ареалах российских морских акваторий: на Дальнем Востоке [18], [28], в Арктической зоне [2], [28], в балтийских регионах [10], [19], Мурманской области [4], [13], Черноморском ареале [7], в том числе в Республике Крым и г. Севастополе [5]. Особое значение приобрело исследование вопросов трансграничной и трансакваториальной кластерной интеграции, в том числе - с участием морехозяйственных отраслей [7], [11], [12], [19], [24]. Ведущая роль морского транспорта и его интегративные способности по отношению к другим отраслям и видам транспорта [12], [23], [24] способствовали формированию специальных подходов к исследованию его в русле формирования целостного транспортного кластера приморского региона как особой разновидности [10], а также изучению ресурсов его роста и повышения устойчивости через призму формирования добавленной стоимости [9].

На текущем этапе потребности региональной экономической политики в области обеспечения безопасности и устойчивости западных приморских регионов требуют более углублённого изучения тех внутренних механизмов и факторов, благодаря которым происходит формирование резистентных свойств морехозяйства (как в отраслевом и пространственном разрезе, так и в целостности взаимосвязанных отраслей и пространственных ареалов), в том числе с выявлением роли кластеров и иных форм структурной организации приморской экономики в этом процессе. Для достижения данной цели осущствим теоретико-концептуальное моделирование процесса самоорганизующего- ся формирования резистентности морехозяйственного комплекса по отношению к геоэкономической нестабильности, а также проведём эмпирическую верификацию модели, выявив соответствующие тренды на примере всех приморских регионов западного порубежья России, включая: Краснодарский край, Ростовскую, Калининградскую, Ленинградскую, Мурманскую и Архангельскую области, Республику Карелия, Республику Крым и г. Севастополь.

Геоэкономические турбулентные явления, возникающие вследствие диспаритета нелинейных и диссипативных свойств региональной экономической системы и проявляющиеся через диспаритет скоростей протекания социальноэкономических процессов (как в «скалярном», так и в пространственном смысле) [8] имеют в основе своего разрушительного воздействия частичную или полную контрцикличность по отношению к региональному воспроизводственному циклу. В свою очередь, она приводит к «выпадению» отдельных структурных звеньев вследствие десинхронизации и пространственного рассогласования производственных, обменных, инвестиционных, технологических и информационных процессов, а также динамики массового сознания, определяющей уровень лояльности по отношению к региональным брендам и доверия между экономическими субъектами, а также между административными и бизнес-элитами [6]. Продолжительный эффект воздействия обусловлен самоорганизующейся природой турбулентных явлений, воспроизводящихся через поддерживающиеся (в том числе - автокатализирующиеся) колебания как в экономическом пространстве (колебания ключевых показателей экономической деятельности, не соответствующие циклической логике регионального воспроизводства), так и в географическом отношении (пространственные вихри, смена направлений перемещения товарно-денежных, миграционных и информационных потоков) [8]. Соответственно, преодоление разрушительного эффекта возможно в следующих случаях:

- При формировании условий для усиления диссипативных (способности к сохранению деловых контактов и схем взаимодействия в новых условиях) и балансировки нелинейных (сдерживание отрицательного инвестиционного мультипликатора и процессов нелинейного роста трансакционных издержек и недоверия в среде субъектов экономики и управления) свой- 
ств регионального воспроизводства.

- При формировании встречного потока, компенсирующего воздействие турбулентной динамики в контрциклической (по отношению к региональному воспроизводству) фазе, а также максимальном использовании возможностей проциклической фазы (прежде всего - реализации программ импортозамещения, создании новых производств в образовавшихся рыночных нишах на местном рынке) [8].

- При балансировке между собственно экономическими и геопространственными векторами колебаний (перераспределение географии поставщиков и рынков сбыта) [8].

- При наличии (либо формировании) в региональной экономической системе подсистем, обладающих сильным и относительно самодостаточным воспроизводственным циклом. Таковые подсистемы, перенимая на себя (либо усиливая уже сформировавшуюся) ведущую роль в региональном хозяйстве, на период турбулентных потрясений становятся опорными драйверами развития всей системы даже в том случае, когда остальные структурные звенья сами по себе не проявляют стойкость по отношению к внешним колебаниям.

Bсе перечисленные возможности защиты региональной экономики взаимосвязаны, а их пропорция зависит от начальных условий столкновения регионального воспроизводственного цикла с турбулентным. Однако если первые три относятся к самоорганизующейся компенсации на уровне текущей краткосрочной и среднесрочной адаптации, то последнее в большей мере формирует стратегические механизмы долгосрочной устойчивости - собственно резистентность. В этой связи встаёт вопрос, какие именно из составляющих региональной экономической системы могут взять на себя таковую роль. В свою очередь, они должны соответствовать следующим критериям:

- сравнительные конкурентные преимущества (в системе национального хозяйства, в потенциале - также на международном уровне);

- наличие устойчивого спроса (в первую очередь на внутреннем рынке, а также на внешних);

- структурная устойчивость за счёт комплексной целостности и либо образования самоподдерживающихся структур как следствия самоорганизующихся процессов, прежде всего - образования региональных кластеров (что, в свою очередь, также происходит благодаря наличию конкурентных преимуществ и исторической развитости отрасли в регионе, либо роста инновационного потенциала).

Как правило, данным условиям соответствуют профильные отрасли, глубоко укоренённые в региональном хозяйстве, располагающие достаточной организационной критической массой, финансовыми ресурсами для покрытия рисков, а также развитой сетью контактов с поставщиками, субподрядчиками и системами сбыта как на внешнем, так и на внутреннем рынке. Однако обращает на себя внимание и тот факт, что под данные критерии во многих случаях подходит морехозяйственный комплекс - даже при условии, что он не является профильной отраслью первостепенной значимости для региона.

Данное обстоятельство обусловлено тем, что приморское положение как таковое является задаваемым естественными природными факторами конкурентным преимуществом региона (если не используемым на практике, то потенциальным). Даже при отсутствии абсолютных преимуществ на глобальном рынке приморские регионы обладают сравнительным преимуществом в системе территориального распределения труда в рамках национальной экономики. Как и ряд других отраслей, период турбулентных внешнеэкономических проявлений они способны переориентироваться на внутренний спрос, тем самым упрочивая свои позиции и укрепляя региональный бренд. При этом в силу своей специфики (зависимости от природных факторов и пространственно-географической локализации, производственно-технологических особенностей и пр.) морехозяйственные отрасли обладают собственным, ярко выраженным, сильным и устойчивым по отношению к внешним колебаниям циклом, коррелирующим также с региональным воспроизводством. Данную особенность отмечает целый ряд исследователей; в частности, по мнению С. Савельевой, исследующей специфику организации регионального морехозяйственного комплекса, в качестве своего важного свойства он имеет «единое территориально-экономическое пространство, потенциально обладающее целостностью воспроизводственного процесса» [20].

Таким образом, морехозяйственный комплекс сам по себе способен создавать встречный поток, осуществляя импортозамещение как по отдельным своим звеньям, так и в их си- 
нергетическом взаимодействии (в том числе с включением инновационной компоненты); он способен участвовать в балансировке процессов пространственного перераспределения рынков сбыта за счёт возможностей морского транспорта, а также переориентироваться на устойчивый внутренний спрос; стабильностью собственного воспроизводства он создаёт относительно устойчивые циклические аттракторы в фазовом пространстве регионального хозяйства, которые способны стать опорными для поддержания поступательного развития региона. Следует отметить и ещё одно важное обстоятельство: наряду с относительной самодостаточностью и наличием собственных конкурентных преимуществ морехозяйственный комплекс способен выполнять интегративную функцию в структуре регионального воспроизводства за счёт межотраслевого взаимодействия, обслуживая интересы экспортных профильных отраслей благодаря возможностям морского транспорта, а также в условиях образования новых ниш на внутреннем рынке создавать условия для развития обрабатывающих отраслей и инновационнотехнологических звеньев в цепочке добавленной стоимости (см. Схему 1).

Проведённое теоретическое обоснование требует эмпирической верификации. Также в связи с обозначенными позициями встаёт вопрос о достижении внутренней структурной устойчивости морехозяйственного комплекса, в том числе за счёт самоорганизующихся процессов, самоподдерживающихся связей и межорганизационных объединений. В связи с этим обратимся к обзору и анализу ситуации, сложившейся в современной практике российских регионов [30].

В Краснодарском крае морехозяйственный комплекс полноправно может считаться профильным, вместе с рядом других отрас-

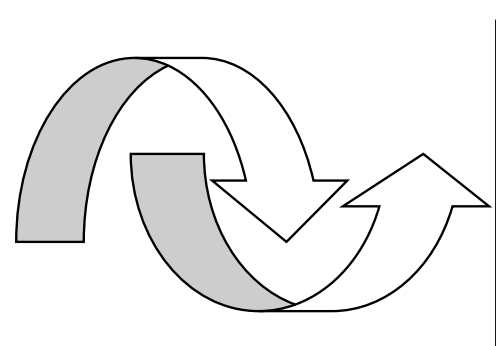

Турбулентный поток
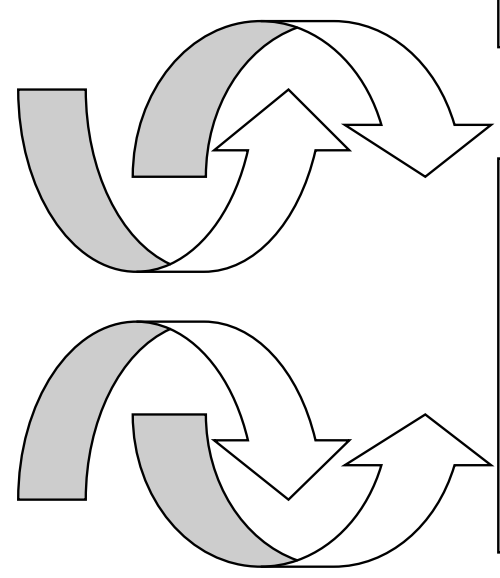

Кооперация с другими отраслями

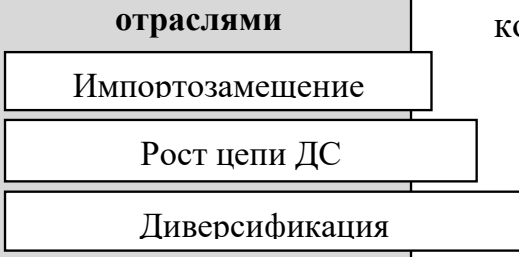

Маневренность географии сбыта

Межотраслевое комплексообразование и кластеризация

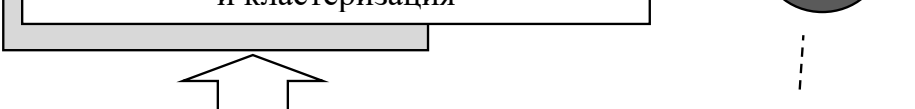

Морехозяйственный комплекс

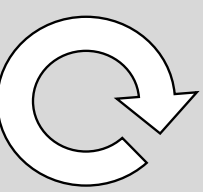

Внутриотраслевое комплексообразование и кластеризация

Собственный сильный цикл

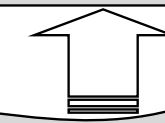

Естественные конкурентные преимущества приморского положения региона
Формирование устойчивых резистентных структур

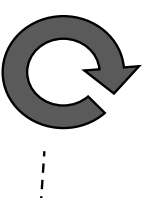

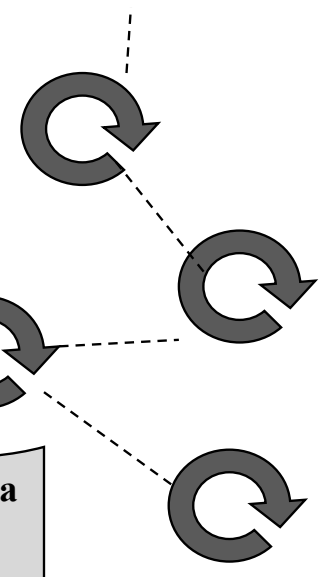

Схема 1. Геоэкономическая турбулентность и резистентные свойства морехозяйственного комплекса 
лей (в первую очередь - АПК). В районах и городских центрах, имеющих непосредственно приморское положение, проживает треть $(33,3 \%)$ всего населения региона (с учётом обслуживающих приморские районы непосредственно примыкающих к ним хинтерландов соответствующая доля составляет более 50\%), сконцентрировано 33,9\% всех предприятий. На территории региона располагаются 9 из 67 зарегистрированных в РФ морских портов, в том числе крупнейший в России - Новороссийск, являющийся одним из главных коридоров экспортно-импортной деятельности федерального значения. Профильной отраслью региона является туристско-рекреационная, в рамках которой основную долю занимают приморские туризм и санаторно-курортное хозяйство.

Прослеживая динамику развития региона до и после 2014 г. (положившего начало активной фазе геоэкономических турбулентных явлений), можно обнаружить повышенную резистентность таких сфер, как морские грузоперевозки и портовое хозяйство. Объём морских грузоперевозок стабильно растёт на протяжении всех последние 5 лет, продолжается технологическое переоснащение, расширение и повышение мощности морских портов Чёрного моря, производятся строительные работы по оборудованию новых портовых комплексов на азовском побережье. Отчасти чувствительность по отношению к внешним изменениям продемонстрировала туристическая отрасль. Динамика численности туристических фирм отреагировала сокращением на 6-7\% в период 2013-2015 гг., после чего восстановила активный рост, а количество реализованных турпакетов начиная с 2014 г. по настоящее время испытывает пост-турбулентную каскадную осцилляцию (в диапазоне вплоть до 30\% попеременного сокращения и роста ежегодно). Наиболее проблемной оказалась отрасль рыболовства и рыбоводства, испытывающая сокращение объёмов производства и финансовых результатов (доля убыточных организаций в отдельные годы за последнее десятилетие достигает 100\%). Однако на подобный вызов организационная среда отрасли отреагировала активным ростом численности предприятий после 2014 г.

Примечательно, что именно благодаря морскому фактору в регионе в 2013-2014 гг. началось образование кластеров - в сфере туризма, подверженное, в свою очередь, субкла- стеризации по территориальному и профильному принципу (образованы 2 кластера на территории «Большого Сочи» - «морской» и «горной» специализации, а также кластер «Абрау-Утриш»). Из сферы туризма кластеризация за последние 2 года проявила тенденцию к распространению вглубь территории, в другие отрасли регионального хозяйства (машиностроение и др.). Однако обращает на себя внимание отсутствие кластерогенных тенденций как в сферах портового хозяйства, морского транспорта и судоремонтных предприятий (как и в регионе в целом, они развиваются по холдинговой, а не кластерной модели, при этом составляя взаимодополняющий и территориально сконцентрированный комплекс), а также в наиболее проблемных сферах рыбного хозяйства (возможно, к образованию кластера приведёт активный рост организационной «критической массы» за последние 5 лет как ответ на внешние вызовы).

В Ростовской области фактор приморского положения не столь очевиден по внешним признакам (в г. Таганроге и двух муниципальных районах, имеющих непосредственное приморское положение, проживает 10,2\% населения региона, располагаются 9,7\% предприятий). Однако с учётом того, что терминалы морского порта г. Ростова-на-Дону расположены в дельте р. Дон, приморский фактор оказывает существенное влияние на жизнедеятельность регионального центра и прилегающих районов (прежде всего Аксайского, располагающего самостоятельными портовыми терминалами).

Как и в Краснодарском крае, наиболее уязвимым звеном МХК оказалась рыбная отрасль: в 2014 г. резко сократились объёмы производства и сальдированный финансовый результат, хотя доля убыточных предприятий и не достигала 100\%. Динамика численности организаций и их производственного результата подвержены осцилляции за последние 5 лет без выраженного единого тренда. Развитие портового хозяйства и морских грузоперевозок происходит в регионе интенсивно на протяжении последних двух десятилетий. Несмотря на отсутствие масштабного технологического обновления портовых терминалов (в отличие от Краснодарского края, где в крупнейших портовых центрах России оно оказалось возможным благодаря федеральной поддержке), в регионе создана конкурентная среда за счёт сосуществования нескольких портовых организаций с различным функционалом, 
в том числе - созданных агропроизводителями. Взаимная диверсификация портового хозяйства, морского транспорта и агропроизводства способствовала совместной кластеризации отраслей (на базе групп агропроизводителей «Юг Руси», «Астон» и др.), развитию конкурентного пространства, что сформировало существенный ресурс резистентности региона. Несмотря на турбулентные колебания в большинстве отраслей (наряду с собственно экономическими показателями проникшие также в среду взаимодействия бизнес-сообщества и региональных элит) регион демонстрирует стабильный рост экспорта (в первую очередь - за счёт продукции АПК), наряду с активным ростом морских грузоперевозок. Сам контактный потенциал и корпоративная культура крупных агрокластеров формировались во многом благодаря наработанным связям морских перевозчиков, что сформировало региональный бренд и создало ресурс прочности в изменившихся условиях.

Подвергся кластеризации и сектор наукоёмкого машиностроения, в том числе - специализирующегося на морских технологиях и оборудовании (рыбопоисковое эхолакационное оборудование, морская авиация, высокоточное приборостроение и пр. в кластерах «Морские системы» и «Южное созвездие»), что было инициировано сменой геоэкономической обстановки и потребностью в импортозамещении. Самоорганизация деловой среды при интегрирующей роли образовательных и научных центров региона сформировала тем самым новые «ядра устойчивости», имеющие потенциал к инновационному росту. На фоне данной тенденции по сей день остаётся лишь потенциальной неоднократно обсуждавшаяся в регионе инициатива по формированию судостроительногосудоремонтного кластера (при наличии конкурентных преимуществ в секторе производства малых судов, вспомогательного флота).

В Республике Крым и г. Севастополе как морской туризм, так и другие отрасли морехозяйственного комплекса являются профильными, на территории полуострова располагаются 5 торговых, 1 рыбный порт. После включения в состав РФ активные меры по компенсации негативных последствий экономических санкций, а также переориентация на российский рынок способствовали росту в ряде секторов. В частности, активно возрастает численность субъектов рыболовства и рыбоводства, снижается доля убыточных предприятий в Республике Крым, нестабильная, но в целом положительная динамика наметилась в г. Севастополе. Сфера туристических услуг как по численности организаций, так и по численности реализованных турпакетов активно росла, достигнув кульминации в 2016 г. (по сравнению с 2014 почти в 5 и 2 раза соответственно), после чего наметился очередной спад (на 40\% и 50\%).

Кластерообразование морехозяйственных отраслей на Крымском полуострове претерпевает сложные и неоднозначные изменения в процессе экономической интеграции в российское пространство. Практически сформировавшийся к 2012-2013 году и имевший конкурентные позиции на международном рынке севастопольский кластер судоремонта претерпел существенные изменения в результате длительного периода адаптации к российской системе тендеров, новым правилам документооборота и отчётности, перераспределения собственности и влияния со стороны крупного российского капитала. Произошло «сжатие» местной деловой среды, сокращение конкурентного потенциала и международной конкурентоспособности (как вследствие утраты части прежних рынков изза прямых санкционных запретов, так и вследствие увеличения сроков выполнения заказов из-за возникших новых институциональных барьеров). В результате период окончательного формирования кластера был смещён по времени на 5-6 лет и пришёлся на настоящее время и ближайшие 2-3 года, уже с участием инорегионального крупного капитала (прежде всего - из Санкт-Петербурга). Кластеризация в области туризма носит скорее формальный, программностратегический характер, направленный на поддержку не самых процветающих и конкурентоспособных курортных центров. В целом, развитие туристической отрасли так же испытывает адаптационный период, однако при этом она остаётся важнейшей профильной.

В Калининградской области, где рыболовная отрасль активно развивалась в советский период и претерпела длительный кризис в 1990-2000 гг., при нестабильной динамике численности организаций их сальдированный финансовый результат после 2014 г. резко возрос (за период 2014-2016 гг. более, чем в 5 раз, составив 5897 млн. руб.), однако с 2017 г. снова наметился спад. Динамично развивается портовое хозяйство. К портам Калининграда и Балтийска 
в ближайшей перспективе должен прибавиться порт в Пионерском, что способствует расширению функционала и наращиванию мощности морских грузоперевозок. Нестабильной является динамика туристической отрасли.

В области (при отсутствии ярко выраженных профильных отраслей, составляющих основную часть регионального хозяйства и ведущих за собой развитие остальных) ещё в период до 2014 года были образованы 7 кластеров, среди которых 2 имеют приморскую специализацию - судостроительный и туристический (в свою очередь, подверженный территориальной субкластеризации). В силу недостаточности внутреннего потенциала региона образование большинства кластеров происходило в качестве трансграничных при участии (а зачастую и по инициативе) зарубежных партнёров. В результате после негативных геоэкономических последствий после 2014 г. практически всё кластерное пространство было «свёрнуто» вследствие разрушения трансграничных связей. Показательно, что из всего числа кластеров до настоящего времени сохранились именно судоремонтный и туристический (частично так же IT-кластер, наряду с развлекательными и коммуникационными технологиями обслуживающий также интересы морехозяйственного комплекса). В настоящее время Центр кластерного развития КО в первую очередь рассматривает стратегические перспективы развития судостроительного кластера, вместе с активно развивающейся в регионе сферой портового хозяйства и логистики.

В г. Санкт-Петербурге и Ленинградской области, где производство во многом направлено на удовлетворение стабильного внутреннего спроса, динамика рыбной отрасли после 2014 г. не претерпела серьёзных изменений и амплитудных скачков, как и деятельность портового хозяйства, планомерно наращивающего грузооборот. Туристическая отрасль после существенного спада в 2014-2015 в настоящее время возвращается к прежней поступательной динамике. При том, что Санкт-Петербург можно считать одним из наиболее ранних ареалов кластерообразования в России, основной акцент пришёлся на наукоёмкие отрасли в области IT и радиационных технологий, фармацевтики и медицины, высокотехнологичного машиностроения, а также электромеханики и средств обслуживания и поддержания экологии городской среды (что обусловлено потребностями объёмного вну- треннего спроса, в свою очередь, это сделало большинство образовавшихся кластеров устойчивыми к внешним изменениям). Лишь в 2018 г. возникла инициатива по созданию межрегионального (с Ленинградской областью) кластера судостроения и судоремонта, в настоящее время рассматриваемого и в качестве площадки взаимодействия с партнёрами из стран ЕС. Тем самым кластерная форма интеграции может способствовать восстановлению части утраченных контактов.

В Республике Карелия, как и в Ленинградской области и Санкт-Петербурге, практически все показатели морехозяйственных отраслей за последние годы не претерпели существенных изменений. В регионе процесс кластерообразования начался относительно недавно, и кластеры в области морехозяйственной деятельности на данный момент отсутствуют.

В Мурманской области, где из всех регионов Северо-Запада рыбная отрасль наиболее масштабна, после 2014 г. при стабильном уменьшении численности предприятий произошёл пятикратный рост их сальдированного финансового результата (что повторяет ситуацию Калининградской области). Основной спад в туристической сфере пришёлся на 2015-2016 гг., после чего уже произошло восстановление прежнего уровня. Ситуация в области образования кластеров схожа с аналогичной в Республике Карелия: они немногочисленны и находятся в стадии проектирования с неопределёнными перспективами. Из морехозяйственных отраслей в их сферу включился лишь туризм, рассредоточенный по региону без явного тяготения к приморским территориям.

В Архангельской области, где морские отрасли являются для региона профильными, ситуация в области рыболовства дублирует аналогичную в других областях Северо-Запада: 4-5 кратный рост финансовых результатов при постепенном сокращении численности организаций, стабильное существование портового хозяйства и судостроительной отрасли, а также возвращение туристической отрасли к прежним масштабам производства после сокращения объёмов деятельности и числа фирм в период 2014-2015 гг.

Профильные для региона судостроение и судоремонт подверглись кластеризации (при участии федеральной финансовой и организационной поддержки) ещё в 2012 г., объединив 
более 30 участников и войдя в число немногочисленных пилотных проектов общероссийского перечня. В настоящее время, уже реализовав ряд крупных проектов, кластер активно диверсифицирует свою деятельность по различным смежным направлениям (металлообработка и станкостроение, производство судовой мебели, строительство понтонов для плавучих гостиниц, инжиниринговые и информационные услуги и пр.). Вслед за центральным производством происходит вовлечение дополнительных, наращивание высокотехнологичных звеньев добавленной стоимости. На базе кластера создаётся Ассоциация «Кластер судостроения и производства морской техники Архангельской области».

\section{Заключение.}

На основании проведённого обзора и анализа очевидно, что, в целом, подтверждается теоретическая гипотеза исследования о повышенной резистентности морехозяйственного комплекса по отношению к геоэкономическим турбулентным явлениям. При этом был детализирован и выявлен ряд других важных положений, в особенности:

- Наименьшую резистентность из всех отраслей морехозяйственного комплекса обнаруживает сфера рыболовства и рыбоводства, подверженная серьёзным конъюнктурным колебаниям рыночной динамики. Соответственно, данная отрасль заслуживает наибольшего внимания, в том числе прямых инструментов поддержки (направленных на снижение убыточности сектора в южных приморских регионах и численности организаций в северных и северо-западных), а также организационных мер по интеграции организационного потенциала региональной деловой среды, упрочению межотраслевых связей и производственной диверсификации, наращиванию цепочек добавленной стоимости за счёт перерабатывающих звеньев и высокотехнологичного сектора. Наряду с указанными мерами большое значение имеет брендирование региональных морепродуктов на внутреннем рынке со стратегической целью выхода на новые внешние.

- Относительно чувствительной, проявившей реакцию на геоэкономические потрясения, является туристическая отрасль. Тем не менее, она обнаруживает достаточный самоорганизующийся потенциал для преодоления сложившейся ситуации и возвращения к поступательной динамике развития.

- При недостатке собственного организационного потенциала, а также при отсутствии прямой профильной специализации региона наиболее сильные и устойчивые морехозяйственные отрасли (портовое хозяйство, морской транспорт и логистика, судостроение и судоремонт) обретают резистентные свойства через межотраслевые связи и взаимную диверсификацию со смежными отраслями (в том числе профильными для региона), тем самым либо берут на себя роль «ядер устойчивости», либо восполняют структурные пробелы в других отраслях, формируя собственную сильную и устойчивую к внешним колебаниям циклическую динамику.

- Как кластерный сценарий, так и путь комплексообразования приводят к повышенной резистентности. Первый - за счёт интеграционного потенциала самоорганизации деловой среды морехозяйственных отраслей, развития конкуренции, второй - за счёт структурной целостности всех звеньев производственного процесса (при отсутствии конкурентной «критической массы» либо при наличии особенностей сложившейся в регионе деловой культуры и характерных для предприятий сектора организационноправовых форм). Оба пути способствуют становлению внутрикластерного (либо внутрикомплексного) цикла, формирующего основу для общерегиональной резистентности при взаимодействии с другими отраслями.

- Наибольшая специфика реакции морехозяйственного комплекса на текущие изменения характерна для Республики Крым и г. Севастополя, как в силу наиболее сильного, прямого влияния экономических санкций, так и в силу того обстоятельства, что к собственно резистентности по отношению $\mathrm{K}$ геоэкономической турбулентности прибавляются сложности интеграции в российское общеэкономическое, документально-правовое, конкурентно-рыночное, организационное и информационное пространство (что отчасти снижает возможности самоорганизационного потенциала в обретении резистентных свойств).

Исследование выполнено при поддержке Российского научного фонда (проект № 19-18-00005 «Евразийские векторы морехозяйственной активности России: региональные экономические проекu५uи») 


\section{Библиографический список}

1. Агафонов Н.Т. Территориально-производственное комплексообразование в условиях развитого социализма. Л.: Наука, 1983. 187 с.

2. Бакланов П.Я., Мошков А.В., Романов М.Т. Географические и геополитические факторы и направления долгосрочного развития Арктической зоны России // Вестник ДВО РАН. 2015. № 180. С. 5-15.

3. Батурова Г.В. Региональные морехозяйственные кластеры как основа социально-экономического развития приморских территорий // Транспортное дело России. 2012. № 6-2. С. 40-42.

4. Вицентий А.В., Шишаев М.Г., Ершова А.А., Гогоберидзе Г.Г. Концептуальная модель морехозяйственной деятельности в регионе как основа систем информационной поддержки морского пространственного планирования // Труды Кольского научного центра РАН. 2017. № 3-8 (8). С. 77-88.

5. Вольхин Д.А. Экономическая кластеризация в приморских зонах Крыма: факторы, локализация и перспективы развития // Научная мысль Кавказа. 2017. № 3 (91). С. 12-22.

6. Горочная В.В. Кластерообразование и инновационная безопасность в регионах западного порубежья России: инвентаризация и основные тренды развития // Региональная экономика и управление: электронный научный журнал. 2019. № 3 (59). С. 11.

7. Горочная В.В. Трансграничная кластеризация в черноморском регионе как фактор экономической безопасности Юга России // Балтийский регион - регион сотрудничества-2018: проблемы и перспективы трансграничного сотрудничества вдоль Западного порубежья России Материалы международной научной конференции. под редакцией Г.М. Федорова, Л.А. Жиндарева, А.Г. Дружинина, Т. Пальмовского.- Калининград, 2018. С. 74-84.

8. Горочная В.В. Турбулентность в геоэкономике: методический подход к моделированию воздействия на экономическую динамику порубежного региона // Экономика устойчивого развития. 2018. № 4 (36). С. 136142.

9. Гуменюк И.С., Волошенко К.Ю., Новикова А. А. Сценарное моделирование отдельных направлений обеспечения роста экономической эффективности регионального транспортного комплекса российского эксклава на Балтике // Балтийский регион. 2019. № 2. С. 51-72.

10. Гуменюк И.С., Орлов С.В. Калининградская область как территория потенциального формирования транспортного кластера Приморского региона // Балтийский регион. 2014. № 3. С. 121-131.

11. Дружинин А.Г., Горочная В.В., Дец И.А., Лачининский С.С., Михайлов А.С. Трансграничные кластеры в приморских зонах: факторы и особенности развития // Вестник Волгоградского государственного университета. Серия 11: Естественные науки. 2015. № 3 (13). С. 68-79.

12. Дружинин А.Г., Горочная В.В. Производственное комплексообразование и экономический кластерогенез: институциональная специфика приморских зон // Научная мысль Кавказа. 2016. № 4 (88). С. 5-15.

13. Ершова А.А., Вицентий А.В., Гогоберидзе Г.Г., Шишаев М.Г., Ломов П.А. Морское пространственное планирование: возможности для приморских территорий и прилегающих акваторий Мурманской области // Национальные интересы: приоритеты и безопасность. 2018. № 2 (359). С. 269-287.

14. Ивченко В.В. Морехозяйственный комплекс как резерв в преодолении кризиса экономики приморского региона // Вестник Российского государственного университета им. И. Канта. 2009. Вып. 3. С. 26-33.

15. Колосовский Н.Н. Основы экономического районирования,- М.: Наука, 1958. - 278 с.

16. Ларина Н.И. Региональные кластеры и территориально-производственные комплексы как формы территориальной организации пространства // Регион: экономика и социология. 2007. № 4. С. 34-39.

17. Ларина Н.И. Роль кластеров и ТПК в формировании конкурентоспособности регионального хозяйства // Конкурентоспособность и стратегические направления развития региона / Под ред. А.С. Новоселова. Новосибирск: ИЭОПП СО РАН, 2008. С. 98-112.

18. Лесовский Б. Ф., Салтыков М.А. Инновационные основы кластеризации региональной экономики // Научные труды Дальрыбвтуза. 2010. С. 168-179.

19. Приморские зоны России на Балтике: факторы, особенности, перспективы и стратегии трансграничной кластеризации. Под ред. А.Г. Дружинина. М., Сер. Научная мысль Балтийского федерального университета, 2018. 216 с.

20. Савельева С.Б. Методология организации регионального морехозяйственного комплекса, дис.... докт. экон. наук / Савельева Светлана Борисовна. Мурманск, 2006.

21. Территориально-производственные комплексы: предплановые исследования / М.К. Бандман, В.В. Воробьева, В.Ю. Малов и др. Новосибирск: Наука, 1988. 270 с. 
22. Филиппова С.В., Сааджан В.А., Глущенко В.Д. К вопросу формирования морехозяйственных кластеров // Экономика: реалии времени. 2014. № 5 (15). С. 146-151.

23. Druzhinin A.G., Gorochnaya V.V. Economic clusterization and complexion: the specificity of the coastal zones of the South of Russia // Journal of Applied Economic Sciences. 2016. T. 11. № 6. pp. 1017-1025.

24. Druzhinin A.G., Gorochnaya V.V., Mikhaylov A. S., Dets I.A., Latchninsky S. S., Volkhin D.A. Trans-aquatorial clustering within the trend of cross-border international economic interactions // International Journal of Economics and Financial Issues. 2016. T. 6. № S5. pp. 128-135.

25. Druzhinin A.G. The Sea Factor in the Spatial and Socio-Economic Dynamics of Today's Russia // Quaestiones Geographicae. 2019. 38(2).pp. 91-100.

26. Fedorov, G.M., Kuznetsova, T.Y. \& Razumovskii, V.M. «How the proximity of the sea affects development of economy and the settlement pattern in Kaliningrad oblast», Regional Research of Russia, 2017, vol. 7, no. 4, pp. 352-362.

27. Gudev P.A. Azov and Black sea region: New political and legal realities // World Economy and International Relations. 2018. 62(10). pp. 91-102.

28. Kravchuk A.A. Arctic and development of far eastern cluster of Russian shipbuilding // World Economy and International Relations. 2019.63(1). pp. 88-93.

29. Porter M. Competitive Advantage of Nations. N.Y.: Free Press, 1990. 896 p.

30. При анализе эмпирических данных использованы следующие сетевые информационные источники: Федеральная служба государственной статистики. URL: https://gks.ru/ (даты обращения 20.07.2019-17.10.2019); Информационный ресурс СПАРК. URL: http://www.spark-interfax.ru/ru/statistics/region/ (даты обращения: 14.09.2019-18.10.2019); Росморпорт. Федеральное государственное унитарное предприятие. Официальный сайт. URL: http://www.rosmorport.ru/services/seaports/ (даты обращения 20.07.2019-29.10.2019); Единый информационно-аналитический портал государственной поддержки инновационного развития бизнеса. URL: http://www.innovation.gov.ru/page/383?title=\&field_orgtype_tid=All\&field_region_tid=756 (дата обращения: 12.10.2019); Кластерная политика / Инвестиционный портал Ленинградской области. Официальный сайт. URL: http://lenoblinvest.ru/404/itemlist/category/109-klasternaya-politika (дата обращения: 22.09.2019); Кластеры // Министерство экономического развития, промышленности и торговли Калининградской области. Официальный сайт. URL: https://minprom.gov39.ru/deyatelnost/regionalnaya-promyshlennaya-politika/ klastery/ (дата обращения: 29.08.2019); Кластеры Архангельской области: новый принцип региональной экономики. URL: http://pravdasevera.ru/economics/-2546d078 (дата обращения: 29.10.2019); Промышленные кластеры Краснодарского края и Ростовской области. Ассоциация кластеров и технопарков России. URL: http://akitrf.ru/press-center/publikacii-v-smi/promyshlennye-klastery-krasnodarskogo-kraya-i-rostovskoyoblasti/ (дата обращения: 20.08.2019); Промышленные кластеры / Центр развития промышленности Ленинградской области. Официальный сайт. URL: https:/crplo.ru/clusters (дата обращения: 17.09.2019); Судостроительный кластер Архангельской области. Официальный сайт. URL: http://ckao.ru/ (дата обращения: 20.10.2019); Центр кластерного развития Архангельской области. Официальный сайт. URL: https://zkr29.ru/ (дата обращения: 20.10.2019); Центр кластерного развития Мурманской области. Официальный сайт. URL: http://murmancluster.ru/ (дата обращения: 15.10.2019); Центр кластерного развития Республики Карелия. Официальный сайт. URL: http://ckr10.ru/3.html (дата обращения: 13.10.2019); Центр кластерного развития Республики Крым. Официальный сайт. URL: https://business.rk.gov.ru/funds/ckr\#home (дата обращения: 15.09.2019); Центр кластерного развития Санкт-Петербурга. Официальный сайт. URL: https://spbcluster.ru/ cluster/ (дата обращения: 20.09.2019); ФГУП Росморпорт. Официальный сайт. URL: http://www.rosmorport. ru/ (дата обращения: 29.10.2019); Крымские морские порты. Официальный сайт. URL: https:/crimeaports. $\mathrm{ru}$ (дата обращения: 29.10.2019); в исследовании использованы данные проведённого автором экспертного опроса с представителями бизнеса, науки, региональной администрации и общественных структур (17 экспертов по Ростовской области, 7 экспертов по Республике Крым и г. Севастополю). 